\title{
Quality Assessment of Drinking Well Water near Dumpsite at Ogidi-Oloje Ilorin, Kwara State, Nigeria
}

\author{
${ }^{* 1}$ YUSUF, KO; ${ }^{2}$ SADIKU, IB; ${ }^{1}$ ABIOYE, OS \\ *IDepartment of Agricultural and Biosystems Engineering, University of Ilorin, Ilorin, Kwara State, Nigeria \\ ${ }^{2}$ Department of Computer Science, Gateway Polytechnic, Sapade, Ogun State \\ *Corresponding Author Email: kamaru.yusuf@yahoo.com; yusuf.ok@unilorin.edu.ng \\ OtherAuthorsEmail: sibsadiku@yahoo.com; serahofgod@gmail.com
}

\begin{abstract}
This study was conducted to determine the quality of drinking well water near dumpsite at OgidiOloje, Ilorin, Kwara State. Open wells near dumpsite could be polluted due to percolation of chemicals from the decomposition of refuse and scraps of electronic boards having potential of causing diseases to man. Most people at Ogidi-Oloje Ilorin depend on open wells near dumpsite for drinking water during dry season. Water samples were collected from seven open wells $\left(\mathrm{W}_{1}-\mathrm{W}_{6}\right) 9.2$ - $18.2 \mathrm{~m}$ away from dumpsite and the control well $\mathrm{W}_{7}$ was $45.0 \mathrm{~m}$ away from the dumpsite. Physicochemical and bacteriological properties were determined from the water samples during dry season (March, 2019) and rainy season (July, 2019). Phosphate, Cadmium, Lead, Feacal coliform were not detected during dry season but only Feacal coliform was not detected in the water during rainy season. All the values of physicochemical properties of the water were within WHO permissible limits except Iron and Cadmium that above the limits which could cause diseases to mankind. Values of Iron during dry season for six well sources were $3.61,4.02,4.26,3.25,5.14$ and $7.24 \mathrm{mg} / \mathrm{L}$ while values for rainy season and control were $0.715,1.410,0.650$, $0.049,0.780,1.110$ and $0.775 \mathrm{mg} / \mathrm{L}$ (control) but WHO limits is $0.03 \mathrm{mg} / \mathrm{L}$. Concentrations of Cadmium in the water during rainy season were $0.010,0.015,0.015,0.020,0.015,0.015$ and $0.02 \mathrm{mg} / \mathrm{L}$ (control) but WHO limit is 0.003 $\mathrm{mg} / \mathrm{L}$. This study revealed that the water is suitable for consumption during dry season but unsuitable during rainy season.
\end{abstract}

DOI: https://dx.doi.org/10.4314/jasem.v24i2.19

Copyright: Copyright $(\mathcal{C} 2020$ Yusuf et al. This is an open access article distributed under the Creative Commons Attribution License (CCL), which permits unrestricted use, distribution, and reproduction in any medium, provided the original work is properly cited.

Dates: Received: 16 November 2019; Revised: 11 January 2020; Accepted: 22 February 2020

Keywords: well water quality, groundwater pollution, water diseases, dumpsite

\section{INTRODUCTION}

Water is one of the most essential natural resources that is indispensable for survival of human race and the demand for potable water is increasing due to the population growth. Potable water is the water that is safe for consumption without causing any disease to man because it is free from pathogens and chemical constituents are within the acceptable limits. Major sources of water for domestics uses are rivers, ponds, lake, spring, rain water and underground water. Contaminated water can cause water-borne diseases such as typhoid, cholera, dysentery and some other diseases (Hammer and Hammer, 2012). World Health Organisation (WHO, accessed on 22th November, 2019) reported that 3.4 million people mostly children died annually due water related diseases. Water is normally scarce during dry season in Ilorin and some people at Ogidi-Olooje, Ilorin, Kwara state, Nigeria mostly depend on open well within their vicinity as the source of water for consumption and other domestic uses. Some of the open wells at Ogidi-Olooje, Ilorin are very close to domestic dumpsite from which the percolating leachate from the dumpsite could pollute the underground water. Areas that are close to dumpsites or landfills have a greater possibility of groundwater contamination because of the pollution by the leachate from the nearby dumpsites. Contaminated water from the dumpsite is toxic to man which could cause cancer and other diseases if the water has high concentration of heavy metals. There is need to determine the quality of the open well water at Ogidi-Olooje that are very close to the dumpsites to create awareness for people in the area. In Nigeria, open dumping site for domestic waste is commonly adopted both in the rural areas and cities because it is cheap and, in most cases, people don't pay for dumping solid waste at the dumpsite. Al Sabahi et al. (2009) pointed out that open dumpsite is an oldest method of solid waste disposal which is still commonly used in the cities of developing countries. Charles et al. (2013) stated that waste disposal and waste management is still a major problem in some developing countries like Nigeria because solid wastes are disposed indiscriminately at open dumping site and not properly managed. Oyelami et al. (2013) reported 
that percolation of leachate from the dumpsite could lead to serious pollution and contamination of groundwater. Soils behave like a natural sink for pollutants that are released from both natural and anthropogenic sources. Vandana-Partha et al. (2011) reported that decomposition of organic matter in the refuse changes the physicochemical properties of the soil and percolation of leachate could pollute the groundwater. The assessment of soil and groundwater pollution is complex because of the different sources of the pollutants and their variability (Vandana-Partha et al., 2011). Yusuf and Suleiman (2016) found out that water from 10 borehole locations at Sango ward Ilorin, Kwara state contained some heavy metals that were above WHO Standards due to human activities and dumping of refuse close to the boreholes. Drinking of water containing high concentration of some heavy metals such as Cadmium, Chromium, Lead, Manganese and Zinc could cause cancer, kidney disease, mental disorder at infants, neurological disorder and hypertension (SON, 2007). Olatunji (2015) pointed out that quality of underground water depends on the quality of recharge water, atmospheric precipitation, in-land surface water and sub-surface geochemical process. Quality and quantity of chemical constituents of water depends on geologic and ecological factors due to the activities of man on the land. Olatunji (2012) reported that geological formation of the study area in Ilorin is composed of the weathered, partly weathered and fresh crystalline basements rocks. The area underlies by rocks mainly porphiritic granite, gneiss and granite-gneiss and quartz-schist (Olatunji, 2012). Adekeye (2001) also reported that over $80 \%$ of Kwara State in which Ilorin is inclusive as the state capital is underlain by crystalline precambrian basement rocks while the remaining part is underlain by cretaceous and younger sediments. The rocks of the basement complex include granites, amphibolites, granites gneiss, biotite gneiss, migmatites while the younger sediments consist the alternating beds of sand stones, shales and clays (Adekeye, 2001). The top soil of the study area is sandy loam followed by clay soil.

Longe and Balogun (2010) pointed out that high concentration of nitrate has negative effect on infants less than three to six months of age. Nitrate could also be reduced to nitrite which could oxidize haemoglobin to methaemoglobin and this could affect the transportation of oxygen in the body system (Longe and Balogun, 2010). Sugirtharan and Rajendran (2015) concluded that leachate slowly percolates through soil and pollutes the groundwater resource which adversely affect the well water (groundwater) within the vicinity by pollution and make the water not suitable for drinking. Sugirtharan and Rajendran
(2015) recommended that an effective management programme of existing open dumping site and the landfill were necessary to control the environmental pollution. The objective of this study was to determine the quality of water from open wells at Ogidi-Oloje Ilorin, Kwara State, Nigeria near dumpsites.

\section{MATERIALS AND METHODS}

Location of the study: The study was conducted at Ogidi-Oloje, Ilorin, kwara State, Nigeria during dry season (March, 2019) and rainy season (July, 2019). Ilorin lies on latitude $8^{\circ} 30^{\prime} \mathrm{N}$ and longitude $4^{\circ} 35^{\prime} \mathrm{E}$ at an elevation of about $340 \mathrm{~m}$ above mean sea level (Ejieji and Adeniran, 2009). Ilorin is in the Southern Guinea Savannah Ecological Zone of Nigeria with mean annual rainfall of about $1300 \mathrm{~mm}$. The wet season begins towards the end of March and ends in October while the dry season starts in November and ends in March (Ogunlela, 2001). The location of Ogidi-Oloje, Ilorin is shown on the map of Ilorin West from the map of Kwara State as shown in Figure 1. Table 1 shows some physicochemical and bacteriological properties of drinking water and their health implication when the parameters above permissible limit as given by SON (2007).

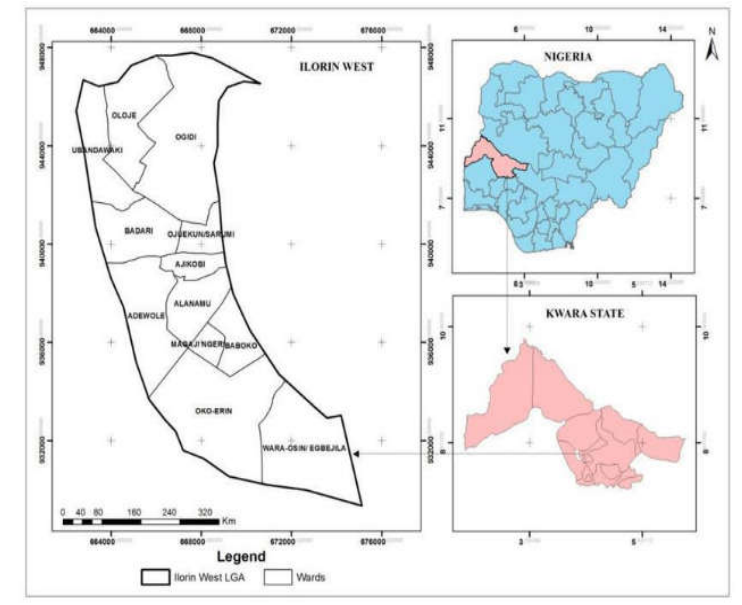

Fig 1. Location of Ogidi-Oloje on the map of Ilorin West from the map of Kwara state. Source: WHO (Accessed on 22th November, 2019)

Computation of paired t-test statistical analysis for this study: A paired t-test statistical analysis was used in this study to check if the effect of nearness or closeness of the open wells to the dumpsite was statistically significant or not on the quality of the water in the well. The difference between the two mean of the water quality based on the chemical parameters of the water was used to determine the mean, standard deviation, standard error and value of t-test using Equations (1), (2a) or (2b), (3) and (4), respectively as given by Montgomery (1998). 
Table 1. Physicochemical and bacteriological properties of water and health implication

\begin{tabular}{ll}
\hline Nitrate & 50 \\
Phosphate & - \\
Turbidity (NTU) & 5 \\
Chloride & 250 \\
Aluminum & 0.2 \\
& \\
Arsenic & 0.01 \\
Barium & 0.7 \\
Cadmium & 0.003 \\
Chromium & 0.05 \\
Copper & 1.0 \\
Cyanide & 0.01 \\
& \\
Fluoride & 1.5 \\
Iron & 0.3 \\
Lead & 0.01
\end{tabular}

Water samples collection and analyses: For this Cyanosis, asphyxia (blue-baby study, water samples were collected from seven (7) syndrome) in infants under 3 pen wells that are available within the vicinity and close to the dumpsites in the study area. Water samples None were collected from six (6) wells during dry season None (March, 2019) but from seven (7) wells during rainy Potential Neuro-degeneratiseason (July, 2019). The distance of the wells to the disorders dumpsites varied from 9.2 to $45.0 \mathrm{~m}$ with $45.0 \mathrm{~m}$ Cancer serves as the control because that was only open well Hypertension far away from the dumpsite that could be assessed with Toxic to kidney the permission of the owner. Locations of the wells Cancer Gastrointestinal disorder and the distance of the wells to the dumpsites are Very toxic to the thyroid and shown in Table 2 for details. nervous system Fluorosis, tooth decay Water samples were collected using cleaned plastic None bottles which had been washed with a detergent, rinsed Cancer, interference with vitaithittap water, 1:1 nitric acid solution and then rinsed metabolism, affect mental with distilled water (cadmium - free de-mineralized development in infants, toxistatedthe The water samples were digested within 6 central and peripheral nervqHSurs by addition of $5 \mathrm{~mL}$ concentrated nitric acid to

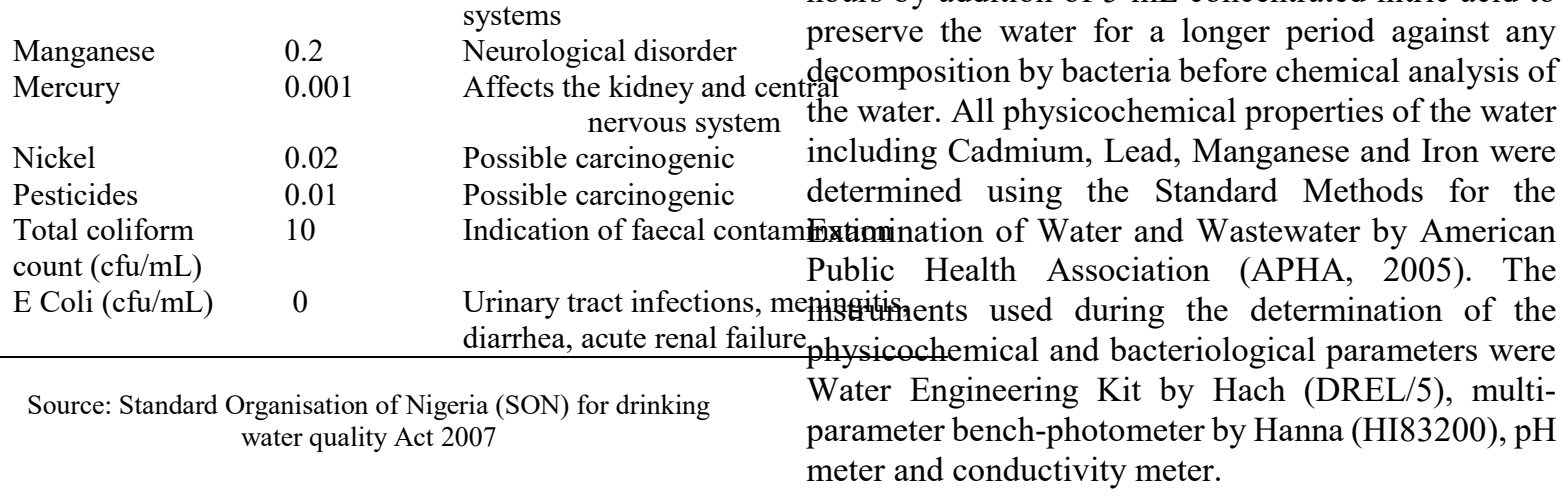

Table 2. Locations of the wells and the distance of the wells to the dumpsites

\begin{tabular}{llll}
\hline $\begin{array}{l}\text { Open well } \\
\text { ID number }\end{array}$ & $\begin{array}{l}\text { Location of the } \\
\text { well }\end{array}$ & Nature of the well & $\begin{array}{l}\text { Distance of well } \\
\text { to dumpsite }(\mathrm{m})\end{array}$ \\
\hline $\mathrm{W}_{1}$ & 28, Ile Councilor & Uncovered and lined & 12.2 \\
$\mathrm{~W}_{2}$ & Annex 3 Estate & Covered and lined & 9.2 \\
$\mathrm{~W}_{3}$ & Al-Jawahir 2 & Perforated cover and unlined & 9.6 \\
$\mathrm{~W}_{4}$ & 22, Ile Onagun & Covered and lined & 10.2 \\
$\mathrm{~W}_{5}$ & Amubioya 1 & Covered and lined & 18.2 \\
$\mathrm{~W}_{6}$ & Amubioya 2 & Covered and lined & 14.4 \\
$\mathrm{~W}_{7}$ & Amubioya 1 & Covered and lined & 45.0 \\
\hline \multicolumn{5}{c}{$\mathrm{W}_{7}$ served as control in this study }
\end{tabular}

The data used for the computation of the paired t-test as an illustration in this study were extracted from Table 5 (Chemical parameters of water closest to dumpsite $9.2 \mathrm{~m}$ which is $\mathrm{W}_{2}$ and $\mathrm{W}_{7}$ which is far away from the dumpsite $45 \mathrm{~m}$ during rainy season) and presented in Table 3. The calculated values of the ttest and that of table values of the t-test were compared if the effect of nearness to dumpsite was statistically significant on the water quality in this study or not.

$$
\begin{aligned}
& \delta=\sqrt{\frac{\sum d^{2}-n(\bar{d})^{2}}{n-1}} \\
& \delta=\sqrt{\frac{\sum(d-\bar{d})^{2}}{n-1}} \\
& \delta_{E r}=\frac{\delta}{\sqrt{n}} \\
& t_{c a l}=\frac{\bar{d}}{\delta_{E r}}
\end{aligned}
$$$$
\bar{d}=\frac{\sum d}{n}
$$ 
Where $\mathrm{d}$ is the mean of the difference from the data $\mathrm{x}_{1}$ and $\mathrm{x}_{2}, \Sigma \mathrm{d}$ is the summation of $\mathrm{d}, \mathrm{n}$ is the number of the observations, $\delta$ is the standard deviation, $\delta_{\mathrm{Er}}$ is the standard error and $t_{\text {cal }}$ is the calculated value of $t$ at $\alpha=$ $5 \%$ significant level which is equivalent to $2.5 \%$ for paired t-test $(\alpha=0.05 / 2=0.025)$.

Table 3. Chemical properties of water used for computation of the paired t-test

\begin{tabular}{lllll}
\hline Parameter & $\mathrm{W}_{2}$ & $\mathrm{~W}_{7}$ & $\mathrm{~d}=\mathrm{W}_{2}-\mathrm{W}_{7}$ & $\mathrm{~d}^{2}$ \\
\hline Nitrate & 8.80 & 6.95 & 1.850 & 3.42250 \\
Phosphate & 1.60 & 2.30 & -0.700 & 0.49000 \\
Chloride & 26.25 & 27.75 & -1.500 & 2.25000 \\
Magnesium & 26.75 & 26.20 & 0.550 & 0.30250 \\
Iron & 1.410 & 0.775 & 0.635 & 0.40423 \\
Calcium & 40.15 & 29.30 & 10.850 & 117.72250 \\
Manganese & 0.030 & 0.040 & -0.010 & 0.00010 \\
Lead & 0.010 & 0.010 & -0.000 & 0.00000 \\
Cadmium & 0.015 & 0.020 & -0.005 & 0.00003 \\
Total & & & $\Sigma \mathrm{d}=11.670$ & $\Sigma \mathrm{d}^{2}=124.59$ \\
\hline
\end{tabular}

$$
\begin{aligned}
& \bar{d}=\frac{11.670}{9}=1.291 \\
& \delta=\sqrt{\frac{124.592-9(1.291)^{2}}{9-1}}=3.701 \\
& \delta_{E r}=\frac{3.701}{\sqrt{9}}=1.234 \\
& t_{\text {cal }}=\frac{1.291}{1.234}=1.046
\end{aligned}
$$

However, the table value of $\mathrm{t}$-test $=2.306$

\section{RESULTS AND DISCUSSION}

The results of physicochemical and bacteriological properties of the water from six wells at Ogidi-Oloje, Ilorin during dry season (March, 2019) were presented in Table 4 while the results obtained in rainy season (July, 2019) from seven (7) wells were presented in Table 5. All the results of physicochemical properties of water assessed during dry season were within the WHO (1996) permissible limits except Iron that was above the permissible limit in all the 6 wells during dry season as shown in Table 4. The higher values of the concentration of Iron in the water could not cause disease to man according to SON (2007). The concentrations of Lead which could cause cancer and Manganese that could cause Neurological disorder were within the permissible limits of WHO (1996) and SON (2007) as presented in Table 4. Total faecal counts was not detected from the water during dry season which means that the faecal had been filtered by the soil profile before the water seeped or recuperated into the open wells. Total coliform counts were higher than the WHO (1996) permissible limits, although it could not cause any disease to man but it is an indication of traces of faecal contamination in the water. Cadmium which is toxic to kidney was not detected in all the well water during dry season. This means that the water from the six (6) wells are suitable for consumption during dry season.

The results of physicochemical properties of the well water during rainy season were higher than the values obtained during dry season. This was so because excess water from precipitation (rainfall) during rainy season dissolves more chemicals from the wastes at the-dumpsite and wash down the chemicals through the soil profile to the groundwater (wells). There is no excess flow of water in the underground that could carry the chemicals to groundwater (well) during dry season. The concentration of Cadmium in all the seven wells water were above the permissible limit of WHO (1996) and SON (2007) and would make the water unsuitable for consumption during rainy season beeause Cadmium is toxic to kidney and could cause kidney disease. The concentration of nitrate at well $\mathrm{W}_{3}$ (Well at Al-Jawahir 2) was higher during rainy season which could cause methemoglobinemia-the blue baby disease (Cyanosis) in infants and stomach disorder in adults as reported by SON (2007). The value of Cadmium was not detected during dry season because there was no migration of the Cadmium and other chemicals from the dumpsite into the wells and this would make the well water suitable for consumption during dry season when water is normally scarce at Ogidi-Oloje Ilorin. The decomposition of materials produced concentrated leachate, which could pollute surface and groundwater (Oyelola et al., 2009) during rainy season. Pollution of well water due to the effect of distance of the dumpsite to the well water by comparing two wells $\mathrm{W}_{2}(9.2 \mathrm{~m})$ and $\mathrm{W}_{7}(45.0 \mathrm{~m}$ away from dumpsite which served as control) was not statistically significant in this study because the calculated value of paired t-test was 1.046 which is less than the Table value of t-test of 2.306 at $\alpha \leq 0.025$ $(2.5 \%)$.

Conclusion: The physicochemical properties of the six wells water assessed during dry season were within the permissible limits of WHO and SON drinking water quality. The physicochemical properties of the seven wells water assessed during rainy season were higher than the values obtained during dry season and values of Cadmium during rainy season were above the permissible limits of WHO and SON. The water from the wells are suitable for consumption during dry season but not suitable for consumption during rainy season due to pollution by the leachate from the dumpsites. Excess water during rainy season help in carrying the contaminants in the leachate produced from the decomposition of refuse in the dumpsites and pollute the wells. It is recommended that more readings should be taken from January to December 
annually to have comprehensive results of the water quality of the wells at Ogidi-Oloje Ilorin, Kwara State. Government at all levels should legislate that dumpsite should be located far away from habitation and far away from wells with at least $1000 \mathrm{~m}$ away to prevent pollution of the groundwater.

Table 4 Results of physicochemical and bacteriological properties of the water for dry season

\begin{tabular}{|c|c|c|c|c|c|c|c|c|}
\hline Water parameter & $\mathrm{W}_{1}$ & $\mathrm{~W}_{2}$ & $\mathrm{~W}_{3}$ & $\mathrm{~W}_{4}$ & $\mathrm{~W}_{5}$ & $\mathrm{~W}_{6}$ & WHO & SON \\
\hline Turbidity (NTU) & 0.14 & 0.11 & 0.13 & 0.14 & 1.84 & 2.16 & 5 & 5 \\
\hline $\mathrm{EC}(\mu \mathrm{S} / \mathrm{m})$ & 130 & 130 & 230 & 230 & 590 & 980 & 1000 & 1000 \\
\hline $\mathrm{pH}$ & 7.50 & 7.40 & 6.90 & 7.20 & 7.50 & 8.10 & $6.5-8.5$ & $6.5-8.5$ \\
\hline TSS (mg/L) & 0.12 & 0.11 & 0.1 & 0.12 & 0.28 & 0.24 & 3 & 3 \\
\hline TDS (mg/L) & 104 & 101 & 168 & 174 & 424 & 703.00 & - & - \\
\hline Nitrate $(\mathrm{mg} / \mathrm{L})$ & 2.61 & 3.02 & 3.14 & 3.15 & 4.08 & 5.12 & 10 & 10 \\
\hline Phosphate (mg/L) & ND & ND & ND & ND & ND & ND & - & - \\
\hline Chloride $(\mathrm{mg} / \mathrm{L})$ & 29.80 & 26.21 & 30.14 & 30.44 & 35.10 & 35.62 & 250 & 250 \\
\hline Magnesium (mg/L) & 1.8 & 1.21 & 1.84 & 1.64 & 2.18 & 2.1 & 150 & 150 \\
\hline Iron $(\mathrm{mg} / \mathrm{L})$ & 3.61 & 4.02 & 4.26 & 3.25 & 5.14 & 7.24 & 0.03 & 0.03 \\
\hline Calcium $(\mathrm{mg} / \mathrm{L})$ & 4.64 & 3.09 & 4.62 & 4.02 & 5.43 & 5.92 & 200 & 200 \\
\hline Manganese (mg/L) & 0.010 & 0.041 & 0.040 & 0.011 & 0.100 & 0.131 & - & 0.200 \\
\hline Lead $(\mathrm{mg} / \mathrm{L})$ & ND & ND & ND & ND & ND & ND & 0.015 & 0.015 \\
\hline Cadmium (mg/L) & ND & ND & ND & ND & ND & ND & 0.003 & 0.003 \\
\hline $\mathrm{TVC}(\mathrm{cfu} / 100 \mathrm{ml}) \times 10^{5}$ & 4.8 & 4.2 & 5.9 & 5.6 & 3.9 & 6.4 & $10 \times 10^{-5}$ & $10 \times 10^{-5}$ \\
\hline $\mathrm{TCC}(\mathrm{cfu} / 100 \mathrm{ml}) \times 10^{5}$ & 2.3 & 2.0 & 3.6 & 3.2 & 1.9 & 4.1 & $10 \times 10^{-5}$ & $10 \times 10^{-5}$ \\
\hline $\mathrm{FCC}(\mathrm{cfu} / 100 \mathrm{ml}) \times 10^{5}$ & ND & ND & ND & ND & ND & ND & 0 & 0 \\
\hline
\end{tabular}

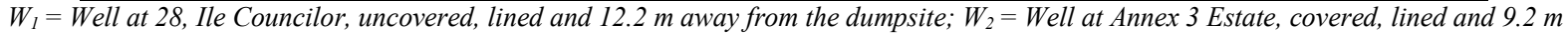
away from the dumpsite; $W_{3}=$ Well at Al-Jawahir 2, perforated cover, unlined and $9.6 \mathrm{~m}$ away from the dumpsite; $W_{4}=W_{\text {ell }}$ at 22, Ile Onagun, covered, lined and $10.2 \mathrm{~m}$ away from the dumpsite; $W_{5}=$ Well at Amubioya 1 , covered, lined, $18.2 \mathrm{~m}$ away from the dumpsite; $W_{6}=$ Well at Amubioya 2, covered, lined, $14.4 \mathrm{~m}$ away from the dumpsite, $N D=$ Not detected, TVC $=$ Total viable counts, TCC $=$ Total coliform counts, Faecal coliform counts. SON = Standard Organisation of Nigeria for drinking water quality Act 2007

Table 5 Results of physicochemical and bacteriological properties of the water for rainy season

\begin{tabular}{llllllllll}
\hline Water parameter & $\mathrm{W}_{1}$ & $\mathrm{~W}_{2}$ & $\mathrm{~W}_{3}$ & $\mathrm{~W}_{4}$ & $\mathrm{~W}_{5}$ & $\mathrm{~W}_{6}$ & $\mathrm{~W}_{7}$ & WHO & SON \\
\hline Turbidity (NTU) & 2.35 & 2.53 & 2.35 & 2.35 & 2.65 & 2.75 & 2.50 & 5 & 5 \\
EC (dS/m) & 560 & 570 & 280 & 285 & 131 & 134 & 535 & 1000 & 1000 \\
pH & 7.0 & 6.6 & 6.7 & 6.8 & 6.9 & 6.8 & 7.0 & $6.5-8.5$ & $6.5-8.5$ \\
TSS (mg/L) & 2.35 & 2.40 & 2.10 & 2.15 & 2.45 & 2.35 & 2.30 & 3 & 3 \\
TDS (mg/L) & 402.5 & 275.5 & 214.0 & 212.5 & 946.5 & 977.0 & 375.0 & - & - \\
Nitrate (mg/L) & 7.75 & 8.80 & 10.15 & 8.35 & 8.12 & 6.85 & 6.95 & 10 & 10 \\
Phosphate (mg/L) & 1.85 & 1.60 & 2.00 & 2.10 & 2.35 & 2.20 & 2.30 & - & - \\
Chloride (mg/L) & 27.50 & 26.25 & 28.05 & 24.70 & 28.25 & 28.40 & 27.75 & 250 & 250 \\
Magnesium (mg/L) & 25.25 & 26.75 & 24.45 & 24.15 & 25.65 & 24.75 & 26.20 & 150 & 150 \\
Iron (mg/L) & 0.715 & 1.410 & 0.650 & 0.049 & 0.780 & 1.110 & 0.775 & 0.03 & 0.03 \\
Calcium (mg/L) & 29.65 & 40.15 & 32.20 & 30.30 & 31.75 & 32.60 & 29.30 & 200 & 200 \\
Manganese (mg/L) & 0.035 & 0.030 & 0.010 & 0.020 & 0.030 & 0.025 & 0.040 & - \\
Lead (mg/L) & 0.010 & 0.010 & 0.010 & 0.015 & 0.010 & 0.010 & 0.010 & 0.015 & 0.20 \\
Cadmium (mg/L) & 0.010 & 0.015 & 0.015 & 0.020 & 0.015 & 0.015 & 0.020 & 0.003 & 0.003 \\
TVC (cfu/100ml) x10 & 250 & 1.2 & 1.6 & 1.7 & 5.8 & 0.64 & 1.30 & $10 \times 10^{-3}$ & $10 \times 10^{-3}$ \\
TCC (cfu/100ml) & 80 & 40 & 40 & 230 & ND & 60 & ND & 10 & 10 \\
FCC (cfu/100ml) & ND & ND & ND & ND & ND & ND & ND & 0 & 0 \\
\hline
\end{tabular}

$\mathrm{W}_{7}=$ Well that is covered, lined but $45.0 \mathrm{~m}$ away from the dumpsite

\section{REFERENCES}

Adekeye, JID (2001). Borehole depths and chemical impurities in groundwater in the basement complex terrain of Kwara State, North Central Nigeria water resources. $J$.Nig. Assoc .Hydrogeologists. 12: 7 - 13.

Al Sabahi, E; Rahim, SA and Zuhairi, WW (2009). The Characteristics of Leachate and Groundwater Pollution at Municipal Solid Waste Landfill of
Ibb City, Yemen. American Journal of Environmental Sciences. 5(3): 256-266.

APHA (2005). Standard methods for the examination of water and waste water, $21^{\text {st }}$ Edition. American Public Health Association, Washington.

Charles, OA; Olabanji, OA; Aladejana J; Abimbola, AJ; Agbede O and Olamide, A.O. (2013). Assessing the Effect of a Dumpsite on Groundwater Quality: A Case Study of Aduramigba Estate within Osogbo Metropolis. Journal of Environment and Earth Science. 3 (1): 120-130. 
Ejieji, CJ and Adeniran, KA (2009). Effect of water and fertilizer stress on the yield, fresh and dry matter production of grain amaranth. Australian J. Agric. Engineer. 1(1):18-24

Hammer, MJ and Hammer, MJ (2012). Water and wastewater technology, $7^{\text {th }}$ Edition, PHI Learning Private Ltd, New Delhi, 40-50.

Longe, EO and Balogun, M. R. (2010). Groundwater quality assessment near a municipal landfill, Lagos, Nigeria. Research Journal of Applied Sciences, Engineering and Technology. 2(1), 39. 44.

Montgomery DC, Runger GC, Hubele NF (1998). Engineering statistics. John Wiley and Sons, Inc. New York, 135-248.

Ogunlela, AO (2001). Stochastic analysis of rainfall event in Ilorin, Nigeria. Journal of Agricultural Research and Development. 39-49

Olatunji, S and Johnson, LM (2012). Determination of seasonal variations of aquifer depth in a part of basement complex of Ilorin metropolis, Journal of Environmental Science and Resources. 4: 67 80.

Oyelami, A; Aladejana, J and Agbede, O (2013). Assessment of the impact of open waste dumpsites on groundwater quality: A case study of the Onibu-Eja dumpsite, southwestern Nigeria," Procedia Earth and Planetary Science. 7: 648-651.
SON (2007). Nigerian Standard for Drinking Water quality, 1-30.

Oyelola, OT; Babatunde, AI and Odunlade, AK (2009). Health implication of solid waste disposal: case study of Olusosun dumpsite, Lagos State. Inter. J. Pure. Appl. Sci. 3 (2):1-8.

Sugirtharan, and Rajendran, M (2015). Ground water quality near municipal solid waste dumping site at Tirupperumthura, Batticaloa. J. Agric. Sci. 10 (1): 21-28.

Vandana-Partha, NN; Murthya, NN and Saxenab, PR (2011). Assessment of heavy metal contamination in soil around hazardous waste disposal sites in Hyderabad city (India): natural and anthropogenic implications. J. Environ. Res.Manage.2 (2): 27-34

WHO (1996). Guidelines for Drinking Water Quality - Health Criteria and other Supporting Information, Second Edition, World Health Organisation, Geneva.

WHO (Accessed on 22th November, 2019). World Health Organisation World Water Day Report

Yusuf, KO and Sulaiman, A (2016). Assessment of heavy metals concentration in borehole water of Sango Ward, Ilorin, Kwara State. Nig. J. Hydrological Sci. 4 (1): 137-146. 